\title{
Observation of dry season polyphenism in Melanitis leda at different altitudinal gradients in Nepal
}

\author{
Bhaiya Khanal \\ Natural History Museum, Tribhuvan University, Swayambhu, Kathmandu, Nepal \\ baya2000@live.com
}

\begin{abstract}
Melanitis leda, a shade loving Satyrid is distributed in tropical to temperate parts of the country. Wet Season Form of this butterfly displays paler wings, prominent eyespots and distinct under wing markings. Dry Season Form remains camouflaged with dry leaf litters mostly in undisturbed parts of the forest floor. This form has diminished eyespots with varying under wing markings. The gradient effect varies location wise which can be assumed to develop different phenotypic forms in this species. Nine such forms of Melanitis leda included in this study were recorded from different forest types of Nepal.
\end{abstract}

Keywords: elevation, eye spots, dry season form, satyrid, wet season form

\section{INTRODUCTION}

Melanitis leda is distributed at $100 \mathrm{~m}$ to $1820 \mathrm{~m}$ of elevations (Khanal \& Smith, 1997) with its rich abundance at warmer region of the country. Individuals of this species occurring at short distance habitats were also observed differing in their wing markings underside.

Season affects the activity and physiology of a butterfly which as per Islam et al. (2010), the dry season form is less active with diminished eyespots while in wet season this butterfly is more active displaying distinct markings and prominent eyespots. Several studies have been made on this species but its phenotypic change and variability between and within seasons has not been analyzed yet (Brakefield, 1987).

Brakefield \& French (1999) mentioned that the wing pattern of a butterfly is the subject to natural selection in context to interactions with predators. Islam et al. (2010) also mentioned that the prominent eye-spots displayed in wet season form of this butterfly have been thought to work as an anti predator device against the attack of vertebrate predators while the lack or reduced spots and markings in dry season form probably relates crypsis for its survival.

\section{MATERIALS AND METHODS}

\section{Study areas}

The change in season, habitats and environmental gradients can be assumed to develop various phenotypic forms of the target species. Nine such forms recorded in different habitat types of the east, central and west Nepal have been considered here.

llam district (Province 1): East Nepal, subtropical mixed forest of Castanopsis tribuloides Castanopsis hystrix, Quercus etc, elevation $1335 \mathrm{~m}$ and geographical position of $26^{\circ} 54^{\prime} 30^{\prime \prime}$ 
$\mathrm{N}$ and $87^{\circ} 55^{\prime} 35^{\prime \prime} \mathrm{E}$.

Jhapa district (Province 1): East Nepal, tropical forest of Shorea robustra mixed with Eriocaulon species, elevation $176 \mathrm{~m}$ and geographical position of $26^{\circ} 33^{\prime} 46^{\prime \prime} \mathrm{N}$ and $87^{\circ} 42^{\prime} 15^{\prime \prime} \mathrm{E}$.

Sunsari district (Province 1): East Nepal, tropical forest of Shorea robusta, elevation $636 \mathrm{~m}$ (Dharan, Bijaypur) and geographical position of $26^{\circ} 49^{\prime} 15.547^{\prime \prime} \mathrm{N}$ and $87^{\circ} 17^{\prime} 27.349^{\prime \prime E}$.

Kathmandu district (Province 3): Pharping, central Nepal, subtropical mixed forest of Aegle marmelos (wood apple), Betula alnoides (Himalayan birch) and Castanopsis, elevation 1455 $m$ with geographical position of $27^{\circ} 36^{\prime} 00^{\prime \prime}$ and $85^{\circ} 16^{\prime} 00^{\prime}$.

Nagarjun, central Nepal (Province 3): Himalayan subtropical broadleaf forests dominated by Schima-Castanopsis trees, elevation $1569 \mathrm{~m}$ with geographical position of $27^{\circ} 47^{\prime} 42^{\prime \prime} \mathrm{N}$ $85^{\circ} 23^{\prime} 24^{\prime \prime} \mathrm{E}$.

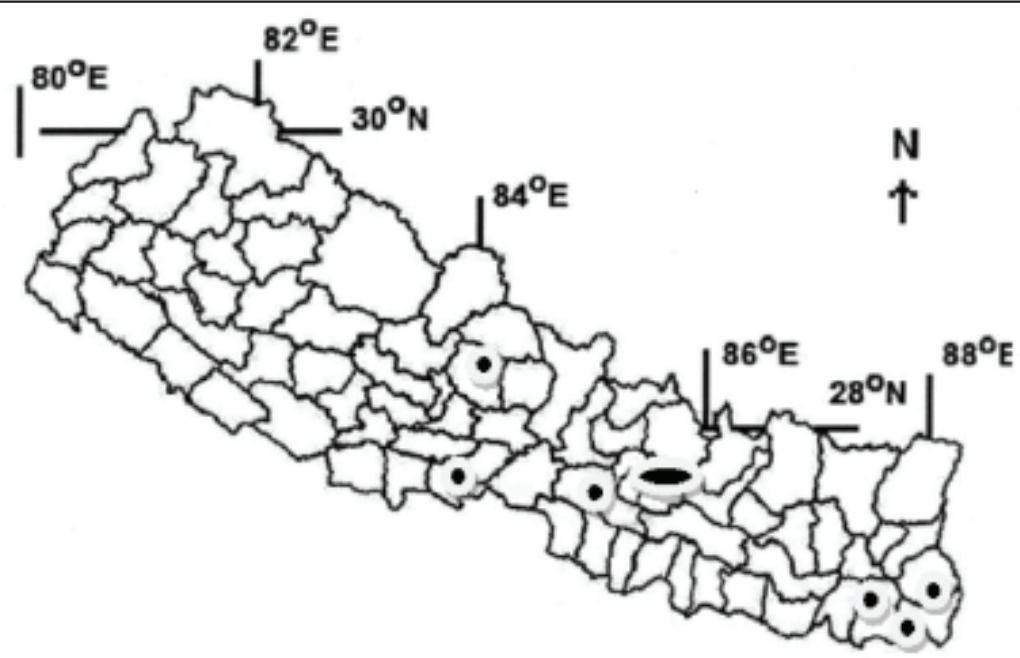

FIG. 1 Black spots in Nepal map indicate study sites.

Bhaktapur district (Province 3): Central Nepal, subtropical mixed forest of Quercus, Alnus, Castonpsis and Schima species, elevation $1440 \mathrm{~m}$ (Suryabinayak forest) with geographical position of $27^{\circ} 38.931^{\prime} \mathrm{N}$ and $85^{\circ} 25.402 ' \mathrm{E}$.

Makwanpur district (Province 3): Central Nepal (Rapti Khola), tropical deciduous forest of Shorea robusta mixed with Dalbergia sisoo, elevation $425 \mathrm{~m}$ with geographical position of $\mathrm{N}$ $27^{\circ} 25^{\prime} 0.012^{\prime \prime} \mathrm{N}$ and $85^{\circ} 15^{\prime} 0^{\prime \prime} \mathrm{E}$.

Kaski district (Province 4): West Nepal (Pokara, Phewa Lake), tropical mixed forest of SchimaCastanopsis, elevation $910 \mathrm{~m}$ with geographical position of $28^{\circ} 13.002^{\prime}$ and $83^{\circ} 57.000^{\prime}$.

Rupandehi district (Province 5): West Nepal (Butwal,Chormara), tropical mixed forest of Shorea robusta with Accacia catechue, Dalbergia sisoo and Bombax ceiba, elevation $151 \mathrm{~m}$ with geographical position of $27^{\circ} 42^{\prime} 1.98^{\prime \prime} \mathrm{N}$ and $83^{\circ} 26^{\prime} 54.095^{\prime \prime} \mathrm{E}$ (fig. 1). 


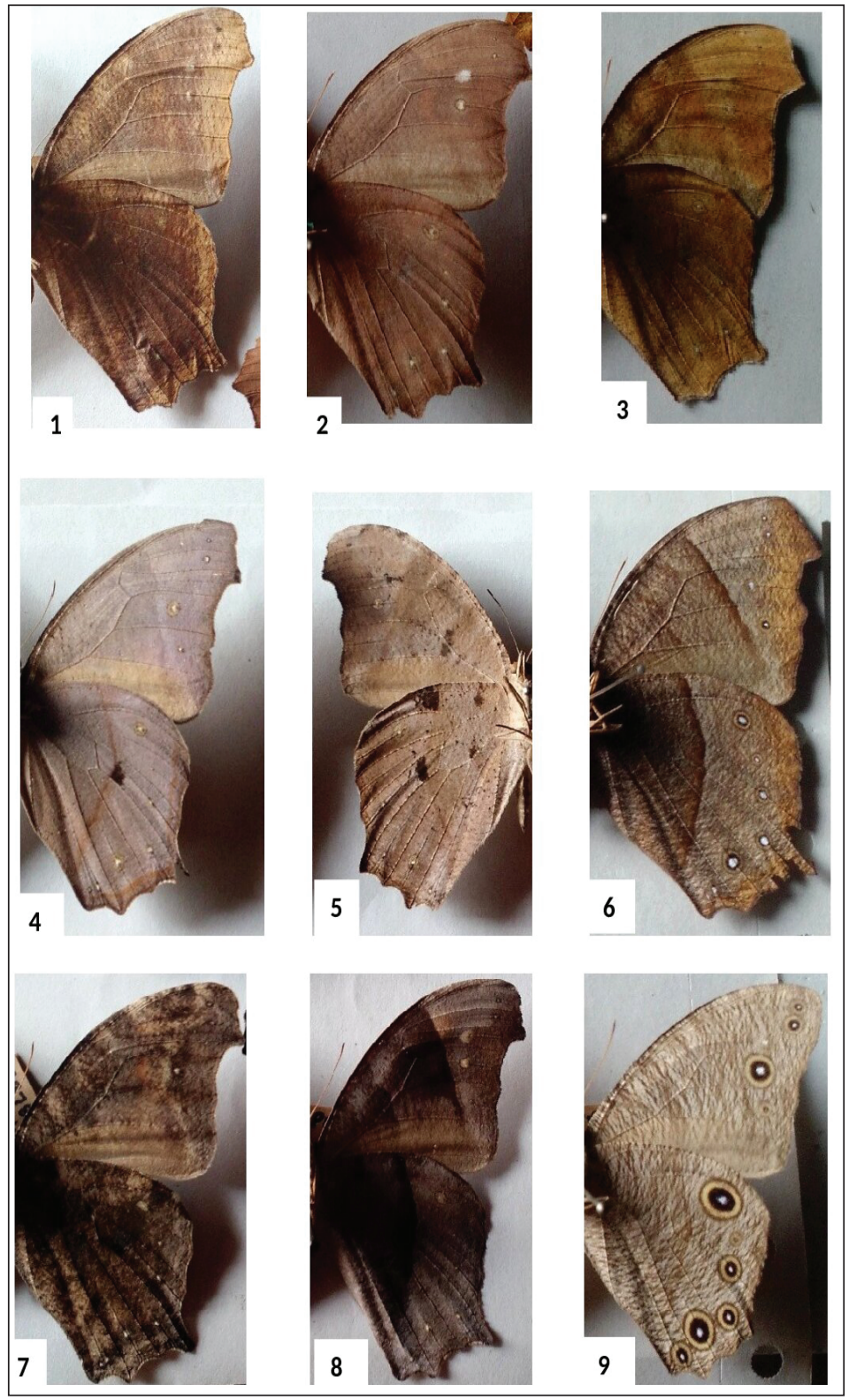

PLATE 1. Dry season forms of Melanitis leda.

Specimens of Melanitis leda deposited at the Natural History Museum in Kathmandu were also consulted for comparative analysis of some seasonal forms. 
Khanal: Observation of dry season polyphenism in Melanitis leda.... .309

\section{RESULTS AND DISCUSSION}

The following phenotypic forms were observed at different forest habitats of Nepal.

\section{Dry Season Form (DSF) Male}

The species recorded in October at elevations of $212 \mathrm{~m}$ and $636 \mathrm{~m}$ showed interesting variations in their under wing pattern though were recorded at the same forest of Shorea robusta. The former species was recorded in Jhapa district displayed yellowish brown underside with brownish broad indistinct bands at the post discal area of FW (plate 1: 1). The next species which was recorded in Dharan $(636 \mathrm{~m})$ presented light brown under wing with two white spots at postdiscal area of FW and small sub marginal spots on HW (plate 1:2).

The species recorded in October at the subtropical forest of Betula alnoides and Castanopsis at $1730 \mathrm{~m}$ of elevation in Pharping, Kathmandu district displayed pale ochreous underside with indistinct brown curve basal line and discal band on both wings (plate 1:3).

\section{Dry Season Form (DSF) Female}

The next form recorded in October in the subtropical mixed forest of Castanopsis and Quercus at1335 $\mathrm{m}$ in llam district displayed light brown under wing color; one black spot on the post discal area of HW, post discal band is more distinct on HW (plate 1: 4).

The species observed in October in the tropical mixed forest of Shorea robusta, Accacia catechue, Dalbergia sisoo and Bombax ceiba at $151 \mathrm{~m}$ in Chormara (Butwal, west Nepal) displayed grayish brown FW underside with blackish diffused spots around basal area. Under HW represented two distinct black spots at subcosta and end cell (plate 1: 5).

Recorded species in September at 1440 m in Quercus, Alnus and Schima forest at Suryabinayak forest (Bhaktapur district) revealed grayish black underwing with diffused markings on both wings. Irregular yellow band on FW and small sub marginal spots are present on HW (plate 1: 7 ).

\section{Dry Season Form (DSF) Female}

The species observed in October in the tropical climate displayed grey under wing with broad post-discal brown band, HW represented distinct concave band (plate 1: 6). Black bordered small white sub marginal spots on both wings. This was observed in Schima-Castanopsis forest at $910 \mathrm{~m}$ in Phewa lake of Kaski district.

\section{Dry Season Form (DSF) Male.}

This was recorded in Schima-Castonopsis forest at $1455 \mathrm{~m}$ of the Nagarjun Mountain of Kathmandu district in monsoon period has dark brown under wing, broad diffused postdiscal band and a small basal band on FW, discal band is concave on both wings. Two small yellowish spots on sub margin of FW and small brown bordered yellow spots on sub- margin of HW (plate 1: 8).

Recorded species in September from the tropical forest of Dalbergia sisoo at $425 \mathrm{~m}$ in Rapti Khola of Makwanpur district displayed pale-grey markings on both wings; white centered black spots are very distinct on both wings (plate 1:9). 
According to Valverde and Schielzeth (2015), different environmental factors which are responsible to bring changes in wing patterns still remain unclear. The darker coloration can be linked to the shaded habitat of forest where enough light cannot reach (plate 1:2,7) and light color of the species in open habitat (plate 1:1) reveals the effect of excessive light, lesser humidity and warmer environment.

Brakefield and Larson (1984) believed that the plasticity in Melanitis is related to the seasonal change in resting background which can be applied to the species of drier habitat that display dry leaf pattern and diminished spots below the costal region (plate 1: 4). The autumn species in cooler environment of mountain presented distinct black spot and darker wings than the species (plate 1: 3 and 4) recorded at the lower elevation where dry condition prevails. Post monsoon species (plate 1:6) with little humid environment in the mountain can be considered to develop darker bands and spots on wings.

Evergreen forest that has moist environment can be linked to the species with distinct dark bands (plate 1:8). The dry season forms occur only in drier months are distinctly characterized with light color patterns. The species (plate 1:9) recorded at the deciduous dry forest with light brown markings and pale gray background can be the effect of the drier habitat condition.

According to Brakefield \& French (1999), the wet season form changes its position on green foliage which causes ventral spots and pale medial band visible distinctly when the butterfly is at rest. They further stated that the species of dry season with light and grey color lack ventral wing markings are well camouflaged on a resting ground among dry leaf litters. The appearance of under wing patterns and increased variability of such patterns are typical changes that may enhance thermoregulation and/or crypsis for the dry season individuals which faced cooler conditions and distinctly different vegetative landscapes (Brakefield \& Larson, 1984; Brakefield, 1987; Douglas \& Grula, 1978; Tauber et al., 1986).

Sultan et al. (2016) made microscopic study on different season scales of $M$. leda revealed the changes that give rise to different wing patterns in this butterfly. They mentioned that the changes are likely to be correlated with behavioral processes such as mate selection and escape from predation. Walia (2001) stated that the first generation of its caterpillar matures into an adult wet season form on feeding green paddy leaf. No edible leaf for caterpillars will be left after ripening paddy so it starts eating grasses which has been thought to develop into an adult of the dry season form. He further stated that the satisfactory explanation for this is still unclear; it has also been thought that the change in host plant is responsible for the appearance of dry season form.

\section{ACKNOWLEDGEMENTS}

Professor Dr. Nirmala Pradhan is appreciated for her photography of the target species.

\section{REFERENCES}

BRAKEFIELD, P M; FRENCH, V (1999) Butterfly wings: the evolution of development of colour patterns. BioEssays 21: 391-401.

BRAKEFILED, P M (1987) Tropical dry and wet season polyphenism in the butterfly Melanitis leda (Satvrinae): phenotypic plasticity and climatic correlates. Biological Journal of the Linnean Society 31: 
175-191.

BRAKEFIELD, P M; LARSON, T B (1984) The evolutionary significance of dry and wet season forms in some tropical butterflies. Biol J Linn Soc 31: 175-191.

DOUGLAS, M J; GRULA, W (1978) Thermoregulatory adaptations allowing ecological range expansion by the Pierid butterfly, Nathalis iole Boisduval. Evolution 32(4): 776. DOI: 10.2307/2407493.

ISLAM, A T M F; RZZAK, M A; ISLAM, M H; SAIFULLAH, A S M; ENDO, K; YAMANAKA, A (2010) Dry and wet season polymorphism in the butterflies, Melanitis leda and Mycalesis mineus (Satyridae: Lepidoptera). Univ J Zool Rajshahi University 29: 33-40.

KHANAL, B; SMITH, C (1997) Butterflies of Kathmandu Valley. TecPass Press, Bangkok, Thailand.

SULTAN, E; SABAT, D; SAHU, B B; MISHRA, M (2016) Structural variations in wing patterning of seasonal polyphenic Melanitis leda (Satyrinae). Microscopy Research 4: 47-54.

TAUBER, M J; TAUBER, C A (1986) Seasonal adaptations of insects. Oxford, U. K.: Oxford University Press, U. K.

VALVERDE, V; SCHIELZETH, H (2015) What triggers colour change? Effects of background colour and temperature on the development of an alpine grasshopper. BMC Evolutionary Biology 15(1): 168.

WALIA, V K (2001) Seasonal occurrence of Melanitis leda ismene (Cramer), Satyridae: Lepidoptera with comments on its dry and wet season forms. Miscellaneous notes, Journal of Bombay Natural History Society 99(1): 137-138. 